\title{
POLITIK DAN KEBIJAKAN TENTANG PENDIDIKAN AGAMA DAN KEAGAMAAN DI INDONESIA (Analisis Kebijakan PP No. 55 Tahun 2007)
}

\author{
Rachmad Sobri \\ Manajemen Pendidikan Islam Magister Fakultas Ilmu Tarbiyah dan Keguruan \\ UIN Sunan Kalijaga Yogyakarta \\ rachmadsobri33@gmail.com
}

Received: 09/11/2018, Accepted: 20/02/2019, Published: 25/02/2019

\begin{abstract}
The article discusses about politics and religious education policy. This condition is motivated by the state's mandate of education. One of which is contained the law number 20/2003 about Indonesian National Education system for every citizen. One of the provisions oe the education system bring goodness to religious education has received less attention from the govermment. Such as boarding school institutions and madrasah educational institutions with the existence of government regulations number 55/2007 about Religious Education Equated with formal education. Religious education institutions get financial aid and educational facilities. Then how religious education in the future with this new education system, where the direction of indonesian religious education in the future. Therefore this article focuses on the religious education system.
\end{abstract}

Keywords: religious, religious education, political.

\begin{abstract}
ABSTRAK
Artikel ini membahas tentang politik dan kebijakan pendidikan agama dan keagamaan. Kondisi ini dilatarbelakangi oleh adanya amanat konstitusi negara terhadap pendidikan. Salah satunya yang terdapat dalam Undang-undang Nomor 20/2003 tentang Sistem Pendidikan Nasional di Indonesia bagi setiap warga. Salah satu ketentuan dari sistem pendidikan tersebut membawa kebaikan bagi pendidikan agama dan keagmaan yang selama ini kurang mendapat perhatian dari pemerintah. Seperti lembaga pondok pesantren dan lembaga pendidikan madrasah dengan adanya Peraturan Pemerintah Nomor 55/2007 tentang Pendidikan Agama dan Keagaaman disetarakan dengan pendidikan formal pada umumnya sehingga lembaga pendidikan agama mendapatkan bantuan keuangan dan fasilitas pendidikan. Lalu bagamana pendidikan agama ke depan dengan adanya sistem pendidikan yang baru ini, kemana arah pednididkan agama di Indonesia ke depannya. Oleh dari itu, artikel ini memfokuskan pada sistem pendidikan agama dan keagamaan.
\end{abstract}

\section{A. PENDAHULUAN}

Pada dasarnya pendidikan adalah salah satu senjata paling realistis dalam menghadapi era globalisasi pada saat ini. Dimana negara itu dikatakan maju banyak sekali aspek-aspek pendukung, salah satunya kualitas pendidikan di suatu negara bagi masyarakatnya. Permasalahan inilah yang dihadapi negara Indonesia yang secara kuantitas jumlah masyarakatnya (SDM) 
menduduki urutan ke-3 terbesar di dunia setelah China dan India, tetapi secara kualitas kita masih di bawah negara tentangga khususnya dalam kawasan ASEAN, seperti Singapura dan Malaysia. Jika dilihat dari segi sumber daya alam (SDA), Indonesia merupakan negara yang kaya akan sumber alamnya, dari tanah saja, segala macam tanaman dapat tumbuh subur, belum lagi kandungan emas di Papua, batu bara di Kalimantan, minyak bumi di lepas pantai Hambalat, kekayaan sumber biota laut yang melimpah belum bisa membuat rakyatnya kaya dan sejahtera serta terbebaskan dari kemiskinan.

Salah satu faktor yang membuat Indonesia masih disebut negara berkembang adalah SDM yang masih lemah dalam mengelola kekayaan alamnya sendiri karena salah satu indikasinya pendidikan di Indonesia yang belum merata, kurangnya tenaga ahli, masih besar angka pengangguran yang disebabkan rendahnya angka pendidikan. Padahal sudah jelas yang diamanatkan Undang-undang Dasar Tahun 1945 Butir 5 yang mengatakan, keadilan sosial bagi seluruh rakyat indonesia. ${ }^{1}$

Jika melihat upaya pemerintah dalam pengambilan kebijakan khususnya di dalam pendidikan yang tercantum dalam Undangundang No. 2 Tahun 1989 Bab III Pasal 5

\footnotetext{
${ }^{1}$ Undang-undang Dasar Pancasila Butir ke-5 Tahun 1945.
}

menyatakan setiap warga negara mempunyai hak yang sama untuk memperoleh pendidikan. Selanjutnya Bab III Pasal 3 menyebutkan pendidikan nasional memiliki fungsi dalam mengembangkan kemampuan dan meningkatkan mutu kehidupan serta martabat manusia dalam rangka mencapai tujuan pendidikan nasional. ${ }^{2}$

Kebijakan di Indonesia bisa berubah tergantung dari segi peta politik dan pemerintahan yang menjalankan roda kebijakan. Oleh karena itu, seiring dengan pergantian kepemimpinan, pemerintahan peta politik pendidikan di Indonesia terus mengalami perubahan dan tentunya kebijakan tersebut harus mementingkan rakyatnya. Sejak era reformasi sistem pendidikan nasional telah mengalami perubahan sistem yang dikeluarkan oleh pemerintah pada masa itu. salah satunya UU No. 20 tahun 2003 pasal I ayat I yang berbunyi pendidikan merupakan usaha sadar dan terencana demi mewujudkan suasana nelajar serta proses pembelajaran bagi pesertaddik secara aktif mengembangkan pontensi yang ada dalam dirinya untuk memiliki kemampuan spritual, keagamaan, kepribadian, kecerdasan dan akhlak mulia yang di butuhkan dirinya, msayarakat negara dan bangsa. ${ }^{3}$ Dari peraturan pemerintah ini

${ }^{2}$ Undang-undang Dasar Nomor 2 Tahun 1989, hlm. 3.

${ }^{3}$ Undang-undang Dasar Nomor 20 Tahun 2003. Sistem Pendidikan Nasional. hlm, 3-4. 


\section{Eduktasi Islaml: Junal Pendidilkan Islam, Vol: 08//No: 01, Februari 2019}

dapat dilihat kebijakan pendidikan masih bersifat nasional dan bersifat wacana, padahal banyak sekali lembaga pendidikan sebelum era reformasi, banyaknya lembagalembaga nonformal, salah satunya pendidikan agama yang belum mendapat porsi khusus dari kebijakan yang pernah dikeluarkan sebelumnya, sehingga pendidikan agama pada masa itu belum bisa dikatakan pendidikan umum.

Sehingga pada tahun 2007, muncullah Peraturan Pemerintah (PP) No. 552007 tentang Pendidikan Agama dan Keagamaan yang merupakan turunan dari sistem pendidikan nasional. Oleh karena itu, dalam pembahasan politik dan kebijakan pendidikan ini apa saja hal-hal penting yang terdapat dalam pendidikan agama dan keagamaan dengan keluarnya kebijakan ini. Berangkat dari bahasan di atas, penulis mencoba memaparkan tentang "politik dan kebijakan pendidikan agama dan keagamaan" sehingga dapat ditarik suatu pemahaman bersama dengan adanya pembahasan ini.

\section{B. KAJIAN TEORITIS}

\section{Pengertian Politik dan Kebijakan}

Politik dapat diartikan sebagai usaha meraih kehidupan yang lebih baik. ${ }^{4}$ Peter Merlk berpendapat bentuk politik yang baik adalah usaha dalam mencapai suatu tatanan

4 Mariam Budiardjo. (2001). Dasar-dasar Politik. Jakarta: PT Gramedia Pustaka Utama. hlm. 13. sosial yang baik dan berkeadilan. Secara luas politik uapaya untuk menentukan peraturanperaturan yang dapat diterima baik oleh sebagian besar warga, agar membawa masyarakat menuju kehidupan yang lebih harmonis. ${ }^{5}$

\section{Dalam Kamus Besar Bahasa} Indonesia politik berarti sebagai. (a) pengetahuan tentang kenegaraan artinya berkaitan dengan sistem pemerintahan, dasar-dasar pemerintahan, (b) segala bentuk dan kebijakan siasat (c) kebijakan merupakan upaya dalam bertindak menghadapi problem tertentu. ${ }^{6}$

Sedangkan menurut Nichols bahwa, kebijakan adalah suatu keputusan yang dipikirkan secara matang dan hati-hati oleh pengambilan keputusan. Pendapat berbeda dari Klein dan Murpy menyebutkan bahwa kebijakan berarti seperangkat atau tujuan, prinsip serta peraturan yang membimbing sesuatu organisasi. kebijakan dengan kata lain mencakup keseluruhan petunjuk dan wewenang organisasi. ${ }^{7}$

Menurut Kamus Besar Bahasa Indonesia kebijakan di artikan kepandaian, kemahiran, kebijaksanaan, kumpulan konsep dan asa yang merupakan poin besar dan dasar perencanaan dalam pelaksanaan

${ }^{5}$ Mariam Budiardjo. (2001). hlm. 15.

${ }^{6}$ Mariam Budiardjo. (1971). hlm. 10.

7 Fachrudin dkk. (2010). Administrasi Pendidikan: Menata Pendidikan untuk Kependidikan Islam. Bandung: Citapustaka Media Perintis. hlm. 146. 
pekerjaan. ${ }^{8}$ Dari pengertian di atas dapat disimpulkan bahwa politik dan kebijakan adalah suatu usaha membentuk suatu peraturan-peraturan melalui keputusan yang diambil oleh pemerintah atau organisasi untuk mengambil suatu langkah keputusan yang akan ditetapkan untuk tujuan tertentu.

Ki Supriyokodi berpendapat pada salah satu tulisannya memberikan uraian serta batasan wilayah kajian dalam politik pendidikan ataralain: ${ }^{9}$

a. Politik pendidikan ialah metode yang digunakan untuk mempengaruhi pihak lain dalam mencapai tujuan pendidikan.

b. Politik pendidikan lebih berorientasi pada bagaimana tujuan pendidikan dicapai.

c. Politik pendidikan berbicara bagaimana metode dalam mencapai tujuan pendidikan, contohnya tentang anggaran pendidikan, kebijakan pemerintah, dan partisipasi pendidikan.

d. Politik pendidikan membahas sejauh mana pencapaian pendidikan sebagai pembentuk manusia Indonesia yang berkualitas, penyangga ekonomi

\footnotetext{
${ }^{8}$ Tim Penyusun. (2001). Kamus Besar Bahasa Indonesia, edisi 3, cet, 1, Jakarta: Balai Pustaka. hlm. 149.

9 Ki Supriyoko. (2007). Hakikat Politik Pendidikan Nasional. Yogyakarta: Pustaka Fahima. hlm. 5 .
}

nasional, dan pembentukan bangsa yang berkarakter.

e. Politik pendidikan serupa
pengertiannya dengan politik ekonomi dan politik kebudayaan.

\section{Pengertian Pendidikan Agama dan Keagamaan}

Peraturan Pemerintah Nomor 55 Tahun 2007 menjelaskan bahwa pendidikan Agama ialah pendidikan yang memberikan pengetahuan serta membentuk sikap, kepribadian, dan keterampilan peserta didik dalam mengamalkan ajaran agamanya, yang di laksanakan sekurang-kurangnya melalui mata pelajaran/kuliah pada semua jalur, jenjang dan jenis pendidikan. Sedangkan pendidikan keagamaan merupakan pendidikan yang membuat peserta didik untuk mampu menjalankan perannya yang menuntut penguasaan pengetahuan tentang ajaran agama atau menjadi ahli imu agama dan mengamalkan ilmu agamanya di masyarakat. ${ }^{10}$

Adapun turunan dari PP. No. 55 Tahun 2007 menjelaskan pendidikan agama dalam Bab II menyatakan: ${ }^{11}$

Pasal (2) berbunyi:

a. Pendidikan agama untuk membentuk manusia indonesia yang beriman dan bertakwa kepada

${ }^{10}$ Pendidikan Agama dan Keagamaan PP No. 55 Pasal 1 dan 2, hlm. 2-6.

${ }^{11}$ Pendidikan Agama dan Keagamaan PP No. 55 Pasal 1. hlm. 2-6. 
Tuhan serta berakhlak mulia dan mampu menjaga kedamaian dan kerukunan hubungan interen atar umat beragama.

b. Pendidikan agama bertujan untuk perkembangan kemampuan yang dimiliki peserta didik agar memahami, menghayati, dan mengamalkan nilai-nilai agama yang menyerasikan penguasaanya dalam ilmu pengetahuan, seni dan teknologi.

Pasal (3) berbunyi:

a. Semua satuan pendidikan di semua jalur, dan jenjang serta jenis pendidikan dan wajib menyelenggarakan pendidikan agama.

b. Pengelolaan pendidikan agama dilaksanakan menteri agama.

Pasal (4) berbunyi:

a. Pendidikan agama dalam pendidikan formal serta program pendidikan kesetaraan sekurangkurangnya diselenggarakan dalam bentuk mata pelajaran atau mata kuliah agama.

b. Setiap peserta didik dalam satuan pendidikan di semua jenjang, dan jenis pendidikan berhak mendapatkan pendidikan agama sesuai agama yang diyakininya dan diajarkan oleh guru/pendidik yang seagama.

Pasal (5) berbunyi:

a. Kurikulum pendidikan agama dijalankan sesuai standar pendidikan nasional.

b. Pendidikan agama diterapkan sesuai dengan tahap pertumbuhan dan kejiwaan peserta didik.

Sedangkan tentang pendidikan keagamaan yang diatur pada Bab III Peraturan Pemerintah No. 55 tahun 2007 sebagai berikut:

Pasal (8) yang berbunyi:

a. Pendidikan keagamaan bertujuan mempersiapkan peserta didik agar menjadi anggota masyarakat yang memahami dan mengamalkan nilainilai, ajaran agamanya serta menjadi ahli agama.

b. Pendidikan keagamaan berfungsi untuk membentu peserta didik yang memahami dan mengamalkan seluruh nilai-nilai keagamaan yang berwawasan luas, kritis, kreatif, serta inovatif, dan dinamis dalam rangka mencerdaskan kehidupan bangsa yang bertakwa, beriman dan berakhlak mulia.

Pasal (9) yang berbunyi:

a. Pendidikan keagamaan meliputi seluruh pendidikan yang di akui oleh negara meliputi, Islam, 
Kristen, Katolik, Hindu, Budha, dan Khonghucu.

b. Pendidikan keagamaan di laksanakan padasetiap jenjang pendidikan formal, nonformal, dan informal.

c. Pengelolaan pendidikan keagamaan dilakukan oleh Menteri Agama.

Pasal (11) yang berbunyi:

a. Peserta didik dalam pendidikan keagamaan jenjang pendidikan dasar dan menengah yang terakreditasi berhak pindah ke tingkat yang setara di Sekolah Dasar (SD), Madrasah Ibtidaiyah (MI), Sekolah Menengah Pertama (SMP), Madrasah Tsanawiyah (MTs), Sekolah Menengah Atas (SMA), Madrasah Aliyah (MA), Sekolah Menengah Kejuruan (SMK) Madrasah Aliyah Kejuruan (MAK) atau bentuk lainnya yang sederajat.

b. Pendidikan keagamaan yang nonformal atau informal dapat dihargai dan dianggap sederajat dengan hasil pendidikan formal keagamaan/umum/kejuruan etelah lulus ujian yang diselenggarakan oleh satuan pendidikan terakreditasi yang telah diberi wewenang oleh pemerintah atau pemerintah daerah. c. Peserta didik dalam pendidikan keagamaan formal, informal, dan nonformal mendapatkan ijazah sederajat pendidikan formal umum/kejuruan semuanya dapat melanjutkan ke jenjang lebih tinggi pada pendidikan keagamaan atau jenis pendidikan lainnya.

Dari definisi di atas dapat disimpulkan bahwa pendidikan agama dan keagamaan merupakan upaya pemerintah dalam menyamaratakan pendidikan yang tertuang dalam Undang-undang No. 20 Tahun 2003 tentang Sistem Pendidikan Nasional. Pendidikan agama lebih kepada pemberian nilai-nilai agama yang berbentuk mata pelajaran agama pada setiap satuan pendidikan sederajat. Sedangkan pendidikan keagamaan lebih kepada upaya pemerintah menyamaratakan pendidikan baik formal, nonformal, dan informal memberikan fasilitas dan hak-hak yang sama pada tingkat satuan pendidikan agama, seperti Pondok Pesanten, MI, MTs, MA, dan Universitas Agama lainnya.

Munculnya PP No. 5 Tahun 2007 mengindikasikan kebijakan pemerintah yang mengakui lembaga pendidikan keagamaan sama dengan pendidikan umum, dimana pendidikan keagamaan ini langsung di bawah naungan Menteri Agama, sehingga pendidikan keagamaan mempunyai hak yang sama baik dari segi 


\section{Eduktasi Islaml: Junal Pendidilkan Islam, Vol: 08//No: 01, Februari 2019}

bantuan dana, fasilitas, kurikulum, dan sebagainya yang menginduk langsung keada Kemendikbud.

\section{ANALISIS DAN PEMBAHASAN}

Dasar-dasar dalam terkainya agama dan negara ini terpatri ke dalam UndangUndang Dasar 1945, baik dalam bagian pembukaan, batang tubuh, dan penjelasannya. Secara eksplisit dasar kontitusional tersebut terdapat pada Sila Pertama Pancasila pada Bab XI UndangUndang 19945 berjudul 'Agama' dalam hal subtansi, keterkaitan antara agama dan negara tersebut mencakup tiga hal utama yaitu: Pertama, Negara menjamin kemerdekaan setiap warga negara untuk memeluk agama, kedua, Negara menjamin setiap warga negara untuk beribadah, dan ketiga, Negara mengakui agama adalah hak asasi interen bagi seluruh warga negara. $^{12}$

Dalam proses kebijakan pengimplementasian pendidikan agama dan keagamaan dalam prinsipnya ialah cara supaya sebuah kebijakan dapat mencapai tujuannya tidak lebih dan tidak kurang untuk mengimplementasikan kebijakan publik, maka terdapat dua pilihan langkah antaralain langsung mengimplementasikan kedalam bentuk

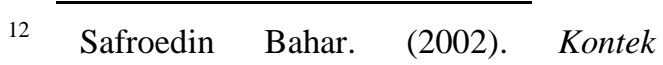
Kenegaraan dan Hak Asasi Manusia. Jakarta: Pustaka Sinar Harapan. hlm. 149. program atau melalui formulasi kebijakan derivat atau turunan dari kebijkan publik tersebut. $^{13}$

Beradasarkan UU No. 20 Tahun 2003 tentang Sistem Pendidikan Nasional bahwa sistem pendidikan Indonesia harus mampu menjamin pemerataan, kesempatan pendidikan, peningkatan mutu serta relevansi dan efisiensi manajemen pendidikan. Pasal 4 Ayat (1) menyebutkan bahwa pendidikan diselenggarakan dengan demokratis serta berkeadilan dan tidak diskriminatif. sehingga menjunjung tinggi hak asasi manusia, nilai keagamaan, kultural, dan kemajemukan bangsa. ${ }^{14}$

Tentang anggaran pendidikan yang diatur dalam sistem pendidikan nasional yang dikemukakan dalam buku Ahmad Rivai, anggaran pendidikan $20 \%$ dapat dilihat secara terperinci dengan teknis pembagiannya adalah $20 \%$ ini total dari APBN pusat, 20\% APBD provinsi, dan 20\% APBD kabupaten/kota. Di pusat itu ada beberapa cabangnya, terbesar itu untuk tahun 2010, misalnya hampir 120 triliun dialirkan melalui Dana Alokasi Umum (DAU) ke daerah, untuk membayar gaji guru, dan operasional awal di sekolahsekolah. Kemudian di Kementerian

${ }^{13}$ Rian Nugroho. (2014). Public Policy, Edisi V. Jakarta: PT Elex Media Komputindo. hlm. 657.

${ }^{14}$ Ismi Dwi Astuti Nurheni. (2009). Reformasi Kebijakan Pendidikan Menuju Kesetaraan dan Keadilan Gender. Surakarta: Lembaga Pengembangan Pendidikan UNS. hlm. 1. 


\section{Politik dan Kebijakan Tentang Pendidikan Agama...}

Pendidikan Nasional (Kemendiknas) di tahun 2010, Rp. 55 triliun kemudian ditambah 24 trilian di Kementrian Agama (Kemenag) lalu ada Dana Alokasi Khusus (DAK) kira-kira Rp. 10,7 triliun dan ada lagi dana-dana yang diberikan kepada kementerian yang memiliki sekolah kedinasan kira-kira 4 triliun sisanya adalah dana Otonomi khusus seperti Papua dan Aceh jadi inilah yang dinamakan dana $20 \%$ dari APBN. ${ }^{15}$

Pembiayaan pendidikan nasional pada dasarnya juga memberikan bantuan kepada lembaga lain atau dialokasikan oleh Kementerian Agama (Kemenag), misalkan di Kemenag, walaupun populasi muridnya berkisar 10\%-15\% dari keseluruhan peserta pendidikan secara nasional, mereka tetap mendapatkan anggaran cukup signifikan. Besarnya sekitar 40\% dari anggaran pendidikan Kemendiknas. ${ }^{16}$ Dari penjabaran di atas dapat penulis lihat bagaimana susunan dan tata cara pembiayaan pendidikan di lingkungan Kementrian Pendidikan hingga alokasi dana diberikan kepada Kementerian Agama untuk mewujudkan pendidikan agama dan keagamaan.

Dengan adanya PP No. 55 Tahun 2007 merupakan angin segar bagi lembaga-lembaga pendidikan agama,

${ }^{15}$ Muhamad Rifai. (2011). Politik Pendidikan Nasional. Yogjakarta: AR-RUZZ Media. hlm. 50.

${ }^{16}$ Muhamad Rifai. (2011). hlm. 50. dimana dengan PP tersebut menjadikan pendidikan agama disamaratakan seperti pendidikan umum. Di sisi lain, diterbitkanya PP No. 55 Tahun 2007 tidak lepas dari kebijakan pemerintah pada masa ke masa, melihat jauh ke belakang secara histori Sistem Pendidikan Nasional (UU Sisdiknas) No. 2 Tahun 1989, menetapkan pendidikan keagamaan sebagai pendidikan luar sekolah (PLS) sama dengan pendidikan umum, pendidikan jabatan kerja, pendidikan kedinasan, dan pendidikan kejuruan. Lebih rinci pendidikan luar sekolah tersebut tertuang dalam Peraturan Pemerintah No. 731991 yang kosekuensinya dari kebijakan tersebut jelas menjadikan lembaga pendidikan keagamaan tidak dapat perlakuaan sejajar dari pemerintah, terutama dalam hak-hak mendapatkan anggaran.

Keadaan berubah setelah terbitnya (UU Sisdiknas) No. 20 Tahun 2003, pendidikan ialah usaha sadar dan terencana untuk mewujudkan suasana belajar serta proses pembelajaran agar peserta didik secara aktif mengembangkan potensi dirinya untuk memiliki kekuatan spiritual keagamaan, pengendalian diri, kepribadian, kecerdasan akhlak mulia, serta keterampilan yang diperlukan 


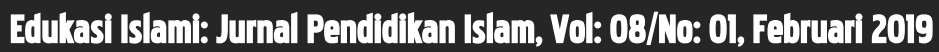

dirinya, masyarakat, bangsa, dan negaranya. ${ }^{17}$

Dari PP No. 55 Tahun 2007 yang secara khusus mengatur pendidikan agama dan keagamaan secara umum, maka keluarlah (PMA) No 3 tahun 2012 tentang Pendidikan Keagamaan Islam. Dimana peraturan ini mengatur tentang penyelenggaraan pendidikan keagamaan yang diatur dalam Bab 1 pasal 1 yang berbunyi: ${ }^{18}$

1. Pendidikan keagamaan Islam merupakan pendidikan yang mempersiapkan peserta didik agar dapat menjalankan peran yang menuntut suatu penguasaan, pengetahuan tentang agama Islam, ahli ilmu agama Islam, dan mengamalkan ajaran Islam.

2. Pendidikan diniyah formal ialah pendidikan keagamaan Islam yang dilaksanakan pada pondok pesantren secara terstruktur dan berjenjang yang terdiri atas pendidikan dasar dan menengah.

3. Pendidikan diniyah nonformal ialah pendidikan keagamaan Islam di luar pendidikan formal yang dilaksanakan baik di dalam maupun luar pondok pesantren

17 Undang-undang Dasar Republik Indonesia Nomor 20 Tahun 2003 tentang Sistem Pendidikan Nasional. hlm. 3.

18 Peraturan Menteri Agama Republik Indonesia Nomor 3 Tahun 2012. hlm. 2-3. dalam bentuk Ma'ahid Aly, diniyah takmiliyah, pendidikan Al-Quran, majelis taklim, pengajian kitab, dan sejenisnya.

4. Pesantren merupakan lembaga pendidikan keagamaan Islam berbasis masyarakat baik sebagai satuan pendidikan maupun sebagai tempat penyelenggara pendidikan.

Pasal 3 berbunyi pendidikan agama Islam meliputi: a. Pendidikan diniyah dan Pesantren. Keluarnya PMA No 3 Tahun 2013 ini dapat disimpulkan bagaimana kebijakan politik yang dilakukan pemerintah dalam menyamaratakan pendidikan umum dan keagamaan khususnya pendidikan Islam yang diatur oleh Kementerian Agama. Sehingga pendidikan keagamaan mendapatkan hakhak yang sama sebagai lembaga pendidikan umum, seperti bantuan dana sekolah, sarana dan prasarana, dan kesejahteraan guru pengajar yang langsung di bawah naungan Kementerian Agama bidang pendidikan. Pendidikan keagamaan yang diatur dalam PMA No. 32012 tentang Pendidikan Diniyah dan Pondok Pesantren menurut analisis penulis merupakan suatu usaha pemerintah untuk mengakui keberadaan pendidikan keagamaan sehingga sebagai masyarakat dalam beragama termasuk dalam pendidikan yang dipilih dapat terealisasi 
serta pemerataan pendidikan di indonesia dapat tumbuh merata tidak hanya pada pendidikan umum milik pemerintah tetapi lembaga pendidikan keagamaan dapat menjadi wadah pendidikan alternatif bagi masyarakat dengan adanya kesetaraan ijazah.

Setelah dikeluarkannya Peraturan Menteri Agama No. 18 Tahun 2014 tentang Satuan Pendidikan Muadalah Pondok pesantren, karena panjangnya penjabaran dari peraturan tersebut dan keterbatasan penulis maka hanya menjabarkan satuan pendidikan muadalah dalam Peraturan Menteri Agama No. 18 Tahun 2014 yang tertuang dalam Bab I pasal I Ayat I yang berbunyi: satuan pendidikan muadalah pada pondok pesantren yang selanjutnya disebut satuan pendidikan muadalah ialah satuan pendidikan keagamaan Islam yang diselenggarakan dan berada di lingkungan pesantren dengan mengembangkan kurikulum sesuai ciri khas pesantren dengan kitab kuning atau dirasah Islamiyah dengan jenjang pendidikan dasar dan menengah di lingkungan Kementerian Agama. ${ }^{19}$

Melihat dari penjabaran di atas, maka penulis menganalisis politik kebijakan pendidikan dari mulai keluarnya PP No. 5

19 Peraturan Menteri Agama Republik Indonesia Nomor 18 Tahun 2014. hlm. 3.
Tahun 2007 tentang Pendidikan Agama dan Keagamaan merupakan upaya pemerintah untuk merangkul lembaga pendidikan agama yang selama ini kurang diperhatikan pemerintah, karena dari data dan fakta di lapangan berapa banyak lembaga pendidikan agama di Indonesia yang selama ini banyak santri dan santriwati di pondok pesantren yang telah berkontribusi bagi bangsa. Hal inilah mungkin menjadi dasar pemerintah lebih memperhatikan pendidikan keagamaan yang sudah dulu ada dari era kemerdekaan, orde lama, orde baru samapai era reformasi sampai saat ini.

Sebagaimana kita tahu mayoritas penduduk Indonesia adalah umat muslim, dan merupakan penduduk muslim terbesar di dunia, secara politik ini merupakan suara terbesar bagi pemerintah yang berkuasa untuk menggalang dukungan, sudah menjadi rahasia umum setiap akan diadakannya pemilu baik presiden, gubernur, walikota, dan anggota legislatif selalu menggunakan unsur keagamaan untuk mendulang dukungan, dengan mendekati tokoh-tokoh agama dan mengunjungi sekolah-sekolah agama. Dampak positif dengan adanya politik ini secara keseluruhan menguntungkan lembaga-lembaga pendidikan agama, dengan adanya kebijakan-kebijakan yang pro terhadap lembaga pendidikan. 


\section{Eduktasi Istaml: Jumal Pendiditkan Islam, Vol: 08//No: 01, Februari 2019}

Contohnya adanya bantuan dana pendidikan bagi lembaga pendidikan agama, adanya kesamaan hak antara lembaga pendidikan umum dan keagamaan, yang terbaru adalah ditetapkannya setiap tanggal 22 Oktober menjadi Hari Santri Nasional oleh pemerintah, melalui Kepres No. 22 tahun 2015.

Lalu yang menjadi pertanyaan, bagaimana arah pendidikan agama khususnya pendidikan agama Islam? Untuk menjawab pertanyaan ini maka penulis akan menjabarkan tentang "Arah Kebijakan dan Strategi pendidikan Islam Tahun 2015-2019" yang terdapat dalam Direktorat Jenderal Pendidikan Islam Kementerian Agama RI sebagai berikut: ${ }^{20}$

1. Mengembangkan akses serta mutu pendidikan anak usia dini diarahkan pada upaya:

a. Meningkatkan dana opersional sekolah berupa BOS untuk RA.

b. Pengadaan ruang kelas pendidikan RA yang berkualitas.

c. Pengadaan peralatan dan perlengkapan pendidikan RA yang berkualitas.

d. Mengembangkan kurikulum yang disertai dengan pelatihan, pendampingan, dan penyediaan

20 Direktorat jenderal Pendidikan Islam Kementrian RI diakses Pada 23 November 2017. buku pendidikan yang berkualitas sesuai kurikulum pendidikan anak usia dini yang berlaku.

2. Peningkatan akses serta mutu pendidikan dasar-menengah (wajib belajar 12 tahun) yang meliputi:

a. Mengembangkan dan perluas akses masyarakat untuk layanan pendidikan.

b. Peningkatan penyediaan sarana dan prasarana yang berkualitas.

c. Mengembangkan mutu peserta didik.

d. Melakukan jaminan mutu kelembagaan pendidikan.

e. Meningkatkan kurikulum dan penerapanya.

f. Meningkatkan seluruh kualitas tenaga pendidik dan tenaga kependidikan.

3. Peningkatan akses, mutu dan relevansi pendidikan tinggi keagamaan meliputi:

a. Meningkatkan akses pendidikan tinggi keagamaan.

b. Meningkatkan kualitas layanan pendidikan tinggi keagamaan.

c. Meningkatkan mutu, dosen, dan tenaga kependidikan perguruan tinggi keagamaan.

d. Meningkatkan kualitas hasil penelitian/riset dan inovasi perguruan tinggi keagamaan. 
4. Peningkatan layanan pendidikan keagamaan yang berkualitas meliputi:

a. Peningkatan akses pendidikan keagamaan.

b. Meningkatkan mutu sarana dan prasarana dalam pendidikan keagamaan.

c. Peningkatan mutu peserta didik pendidikan agama.

d. Peningkatan mutu pendidik dan tenaga kependidikan pendidikan keagamaan.

e. Peningkatan penjaminan mutu kelembagaan dalam pendidikan keagamaan.

f. Peningkatan dar kualitas pembelajaran keagamaan yang moderat pada pendidikan keagamaan.

5. Peningkatan kualitas pendidikan agama dalam satuan pendidikan umum untuk memperkuat pemahaman dan pengalaman untuk membina akhlak mulia dan budi pekerti luhur meliputi:

a. meningkatkan mutu dan pemerataan guru pendidikan agama.

b. Peningkatan mutu dan pemahaman siswa terhadap pendidikan agama. c. Peningkatan mutu kelembagaan pendidikan agama.

6. Peningkatan pada tata kelola pendidikan agama diarahkan pada upaya:

a. Penguatan struktur dan tata organisasi pengelolaan pendidik dalam mendukung penyelenggaraan pendidikan pada semua jenis, jenjang, dan jalur pendidikan.

b. Penguatan lembaga penelitian kebijakan pendidikan dan jaringannya agar dapat menghasilkan kajian-kajian kebijakan dalam pengembangan norma, standar, prosedur, dan kriteria pembangunan pendidikan yang inovatif.

c. Penguatan penyusunan dan penyelarasan peraturan yang menjadi dasar penyelenggaraan pendidikan yang merata, berkeadilan, dan bermutu.

d. Penguatan sistem informasi pendidikan melalui pengutan lembaga dan kapasitas pengelolaan sistem informasi.

e. Penguatan komitmen pengambilan kebijakan dalam penyediaan data informasi pendidikan sehingga 
pengumpulan data dan informasi dapat dilakukan dengan baik.

f. Penguatan kapasitas pengelola pendidikan untuk dapat berperan secara maksimal dalam pengelolaan satuan pendidikan secara transparan dan akuntabel.

g. Peningkatan partisipasi seluruh pemangku kepentingan pembangunan pendidikan untuk memperbaiki efektivitas dan akuntabilitas penyelenggaraan pendidikan di tingkat satuan pendidikan dalam memberikan dukungan bagi satuan pendidikan untuk pelayanan pendidikan.

Hasil arah kebijakan yang telah dijabarkan di atas maka adapun cara yang diterapkan agar tercapainya hal tersebut sebagai berikut:

1. Cara dalam meningkatkan akses pendidikan diniyah dan pondok pesantren berupa:

a. Membuat satuan pendidikan muadalah pada pondok pesantren/ma'ahid aly baru.

b. Pemberian Bantuan Operasional Sekolah (BOS) bagi santri pada pendidikan diniyah formal pada satuan pendidikan muadalah /program persaman lulusan /program wajar dikdas tingkat ula, wustha, ulya, paket $\mathrm{A}$, paket $\mathrm{B}$, serta paket $\mathrm{C}$.

c. Memberikan bantuan dan sosialisasi Kartu Indonesia Pintar bagi santri.

d. Persamaan lulusan/program wajar Dikdas serta paket A, paket B, dan paket $\mathrm{C}$.

e. Pembangunan asrama pondok pesantren.

f. Pembangunan lembaga pendidikan keagamaan baru dan pemberian dukungan pengembangan/ peningkatan mutu, sarana, dan prasarana pendidikan, serta tata kelola di wilayah $3 \mathrm{~T}$ (terdepan, terluar, dan tertinggal).

2. Cara dalam meningkatkan mutu sarana dan prasarana pendidikan diniyah dan pondok pesantren berupa:

a. Rehabilitasi ruang kelas pada pendidikan diniyah formal/satuan pendidikan muadalah pada pesantren.

b. Pemeliharaan asrama pada pondok pesantren.

c. Peningkatan mutu sarana dan prasarana pendidikan agamaan Islam.

d. Meningkatkan mutu lembaga penyelenggara pendidikan keagamaan. 
e. Memberi peningkatan mutu kepada lembaga pendidikan keagamaan sabagai inikator bisnis bagi santri dan pusat pemberdayaan ekonomi masyarakat.

f. Pengembangan pondok pesantren unggulan tafaqquh dan vokasional/keterampilan.

3. Cara dalam meningkatkan mutu santri pendidikan diniyah pada pondok pesantren berupa:

a. Pemberian beasiswa pendidikan Tahfizh Al-Qur'an.

b. Pemberian beasiswa santri berprestasi.

c. Melibatkan santri dalam Perkemahan Pramuka Santri Nusantara (PPSN).

d. Mengikutsertakan santri dalam Pekan Olah raga dan Seni Antar Pondok Pesantren Tingkat Nasional (POSPENAS).

4. Cara dalam meningkatkan mutu pendidikan dan tenaga kependidikan pada pendidikan keagamaan Islam berupa:

a. meningkatkan kompetensi dan kualifikasi guru dan tenaga kependidikan pada pendidikan diniyah, muadalah pada ponpes.

b. Mengikutsertakan pendidik pada pendidikan diniyah, dan muadalah pada pondok pesantren kepada pendidikan profesi guru.

c. Memberi tunjangan fungsional kepada pendidik.

d. Pemberian tunjangan profesi kepada pendidik.

e. Peningkatan mutu pengasuh pesantren.

5. Cara dalam meningkatkan jaminan kualitas (quality assurance) kelembagaan diniyah dan pondok pesantren berupa:

a. Penyiapan akreditasi lembaga pendidikan keagamaan Islam.

b. Peningkatan mutu pembelajaran lembaga pendidikan keagamaan Islam.

c. Penyusunan regulasi pendidikan keagamaan Islam.

d. Penyediaan data pendidikan keagamaan Islam.

e. Penyediaan paket peningkatan mutu manajemen lembaga pendidikan keagamaan Islam.

f. Penyusunan Standar Nasional Pendidikan Keagamaan Islam.

6. Cara dalam meningkatkan kualitas pembelajaran pendidikan Islam yang moderat pada pendidikan diniyah dan pondok pesantren berupa:

a. Penyelenggaraan tahkiq atas kitab karya ulama Nusantara. 


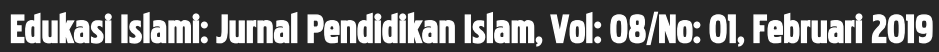

\section{b. Sosialisasi}

pemahaman

keagamaan

yang toleran,

seimbang, moderat, dan cinta tanah air.

c. Pelaksanaan untu deradikalisasi keagamaan pada lembaga pendidikan agama.

Melihat dari penjelasan di atas, maka akan timbul pertanyaan, dimana letak pendidikan RA, MI, MTs, MA, dan MAK? Karena keterbatasan penulis dalam makalah ini dan sudah juga dibahas tentang pendidikan madrasah pada materi sebelumnya, sehingga ini dapat dikatakan beda konteks tetapi sama wadahnya. Karena pendidikan Madrasah (RA, MI, MTs, MA, dan MAK) sudah ada sub bagian tersendiri pada Peraturan Menteri Agama RI No. 90 Tahun 2013 tentang Penyelenggaraan Pendidikan Madrasah. Serta PMA No. 14 Tahun 2014 tentang Pendirian Madrasah. Karena pada dasarnya madrasah dibentuk oleh pemerintah untuk meningkatkan pendidikan serta memenuhi kebutuhan masyarakat akan pendidikan keagamaan. Beda konteks dengan pendidikan keagamaan diniyah dan pondok pesantren yang berdiri sendiri sejak dahulu dan sekarang sudah menjadi pendidikan formal berkat adanya UUD No. 20 tahun 2003 serta PP No. 55 tahun 2007.

\section{KESIMPULAN}

Politik dan kebijakan merupakan suatu cara untuk menetapkan dan melaksanakan aturan yang akan ditetapkan oleh pemerintah atau organisasi dan sekelompok orang untuk mencapai tujuan yang telah ditetapkan. Dengan adanya kebijakan tersebut diharapkan membawa dampak yang positif bagi masyarakat luas. Politik pendidikan agama dan keagamaan sejatinya merupakan suatu kebijakan yang diambil oleh pemerintah untuk menyamaratakan pendidikan di Indonesia dari Sabang sampai Marauke. Maka dari itu, setiap warga negara berhak memeluk agama dengan kepercayaan dan keyakinannya masing-masing. Perubahan Sistem Pendidikan Nasional yang termuat dalam Undang-Undang No. 20 Tahun 2003 tentang Sistem Pendidikan Nasional yang mengamanatkan setiap warga negara memiliki hak untuk memperoleh pendidikan, terutama pendidikan agama yang diatur dalam PP No. 55 Tahun 2007 tentang Pendidikan Agama dan Keagamaan. Sehingga dengan peraturan tersebut lembaga pendidikan agama dan keagamaan disamaratakan dengan pendidikan umum milik pemerintah, dan mendapat hak yang sama pula dalam memperoleh bantuan dana, sarana dan prasarana serta tunjangan bagi pendidik dan peserta didik dalam bentuk bantuan 


\section{Politik dan Kebijakan Tentang Pendidikan Agama...}

oprasional sekolah, sehingga diharapkan pendidikan agama dapat berkontribusi dalam penyamarataan pendidikan sampai ke daerah terluar, terpencil, dan tertinggal. Menciptakan generasi bangsa yang pintar dalam akademik dan berakhlak baik ke depannya.

\section{DAFTAR PUSTAKA}

Direktorat jedral pendidikan islam kementrian RI Diakses Pada 23 November 2017.

Fachrudin dkk. (2010). Administrasi Pendidikan: Menata Pendidikan untuk Kependidikan Islam. Bandung: Citapustaka Media Perintis.

Ismi, D.A.N. (2009). Reformasi Kebijakan Pendidikan Menuju Kesetaraan dan Keadilan Gender. Surakarta: Lembaga Pengembangan Pendidikan UNS.

Kamus Besar Bahasa Indonesia. edisi 3, cet. 1. Jakarta: Balai Pustakan, 2001.
Mariam, B. (2001). Dasar-Dasar Politik. Jakarta: PT Gramedia Pustaka Utama.

Nugroho, R. (2014). Public Policy, Edisi $V$. Jakarta: PT Elex Media Komputindo.

Peraturan Pemerintah. No. 55, Tahun 2007. Tentang Pendidikan Agama dan Keagamaan Pasal 1 dan 2.

Peraturan Menteri Agama Republik Indonesia Nomor 3 Tahun 2012.

Peraturan Menteri Agama Republik Indonesia Nomor. 18 Tahun 2014.

Rifai, M. (2011). Politik Pendidikan Nasional. Jogjakarta: AR-RUZZ MEDIA.

Safroedin, B. (2002). Kontek Kenegaraan dan Hak Asasi Manusia. Jakarta: Pustaka Sinar Harapan.

Supriyoko, K. (2007). Hakikat Politik Pendidikan Nasional. Yogyakarta: Pustaka Fahima. 